\title{
COMPUTERIZED VALUE STREAM SYSTEM (CVSS) TO REDUCE WASTE IN LEAN MANUFACTURING OPERATION
}

\author{
S. Hj. Hasan ${ }^{*}$, A. N. A. Ahmad, and D. Feriyanto
}

Faculty of Mechanical and Manufacturing Engineering, Universiti Tun Hussein Onn Malaysia (UTHM), 86400 Parit

Raja, Batu Pahat, Johor, Malaysia

\begin{abstract}
Lean manufacturing is a popular method of acquiring efficiency in manufacturing environment. Value stream mapping (VSM) is one of the methods that can be used by practitioner to support lean. VSM method is also a common method to identify waste and determined causes of the waste through the value stream mapping approach and propose solutions to improve workplace environment. This project is an attempt to computerize the normally manual VSM process. Computerize value stream system (CVSS) is basically a method which is an internet networking system combined with traditional concept of value stream mapping method used at manufacturing company to reduce wastes. This paper summarizes the way to apply an internet, online and network based of an efficient computerize value stream system to improve operation value of the manufacturing company. This paper reviews the design of the package that will replace the manual method of doing VSM. The system is tested in a real shop floor environment and found to be successful.
\end{abstract}

Keywords: value stream mapping, CVSS, lean manufacturing system, increase productivity, waste reduction

*E-mail address: sulaiman@uthm.edu.my

\section{Introduction}

Traditional manufacturing practices are the thing in the past. Cyber or computerized manufacturing is introduced to increase productivity, shop floor networking to enable data collections and sharing among users within and outside the enterprise, promote efficiency and add value to products. Cyber manufacturing is a manufacturing process and engineering which adopt a networking and make full use of computerization. This allows real-time entries of system data for all the activities that occurred on the shop floor.

This paper explored and investigated how traditional VSM can be computerized and integrated into a computerized manufacturing system. It can be used as a method to reduce non value added activities and develop an efficient system to improve operation value of a manufacturing company.

\section{Lean Manufacturing}

Lean is defined as the systematic removal of waste by all members of the organization from all areas of value stream [1]. Lean is often referred to as a cost reduction mechanism. Lean strives to make organizations more competitive in the market by increasing efficiency, decreasing costs incurred due to elimination of non-value added (NVA) steps and efficiencies in the processes as well as reducing cycle times and increasing profit to for the organization [2,3]. Lean effectiveness is when it produces exactly what is needed in the right amount needed and when it is needed. Lean manufacturing is aimed at elimination of waste in every area of production including customer relations, product design, supplier networks and factory management $[4,5]$.

\section{Computerize Value Stream Mapping (CVSS)}

Value Stream Mapping is one method used to eliminate waste in lean system [6,7]. This is considered as an important tool for efficiency [8]. Value stream mapping from the standpoint of traditional view is currently mostly manual form filling operations, with the use of basic tools for most of the process or operations. However, the traditional VSM has come of age, and has now been implemented in modern practices like the application of modern machinery, networking system, new technology and new method to increase productivity [8].

CVSS is a system or software that can auto calculates total amount data inserted for every process related to VSM. All data that can be auto calculated are total processes of VSM, total of cycle time (CT), total of operator needed, total time of waiting time (WT), total of work in progress (WIP), total of lead time (LT) to finish process from raw material till finish goods, total non-value added time 
(NVA) and total of value added time (VA) as shown in Fig. 1.

CVSS was created as software that can be used at any of manufacturing company that applies VSM and lean method to reduce waste occurs during manufacturing process. CVSS software calculates takt time for every process of manufacturing by inserting the data related into the column of data

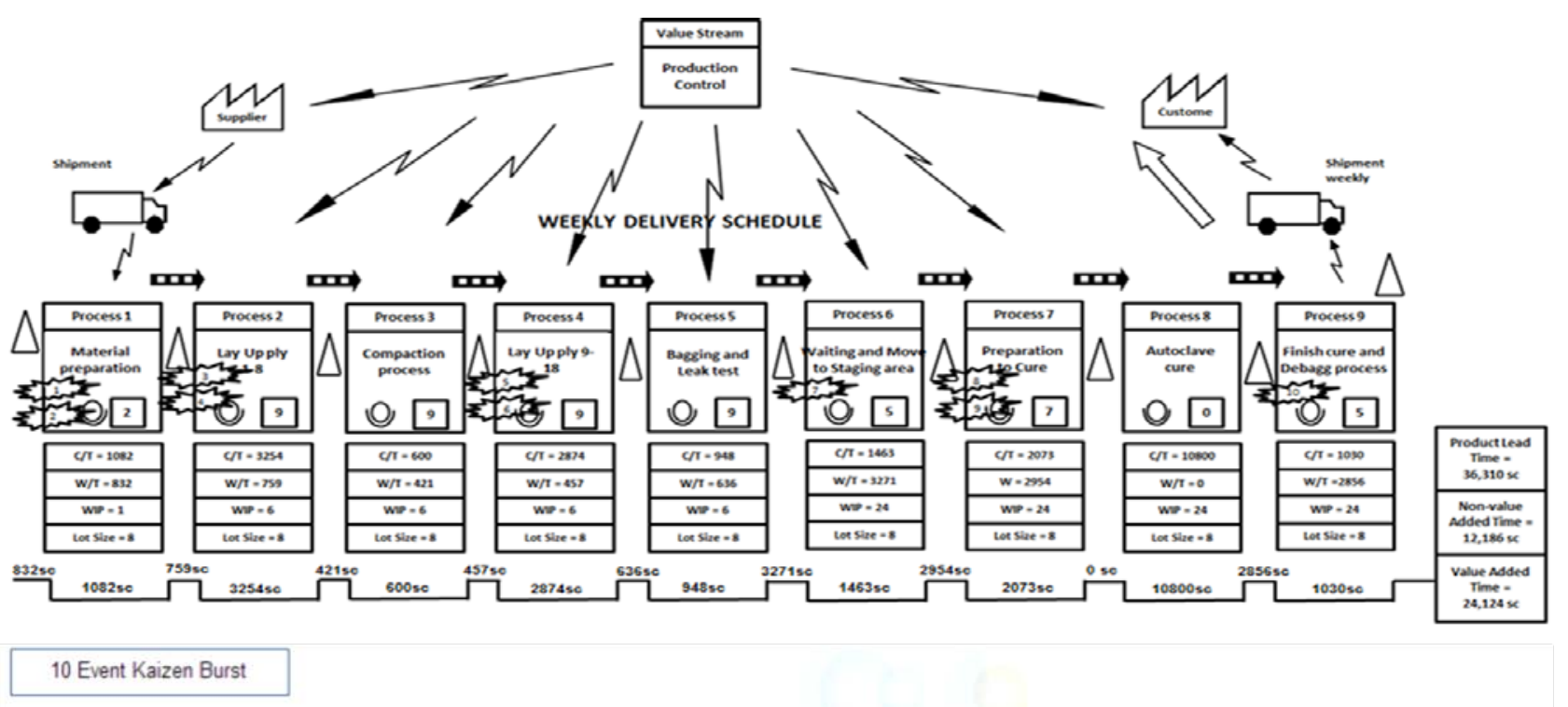

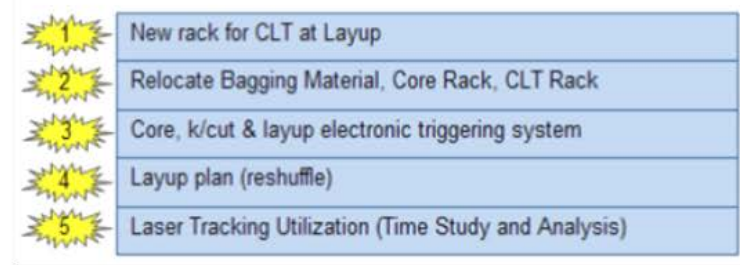

Fig. 1. Current state of CVSS

The ideal times of production that meets the demand and customer requirement. "Takt" is a German word meaning "beat." Takt time is also the table provided by the software. To calculate takt time, user must have a complete set of data consisting of customer demand per day and working hours per day. Using this format, takt time for whole process of production or every process at particular area can be calculated automatically.

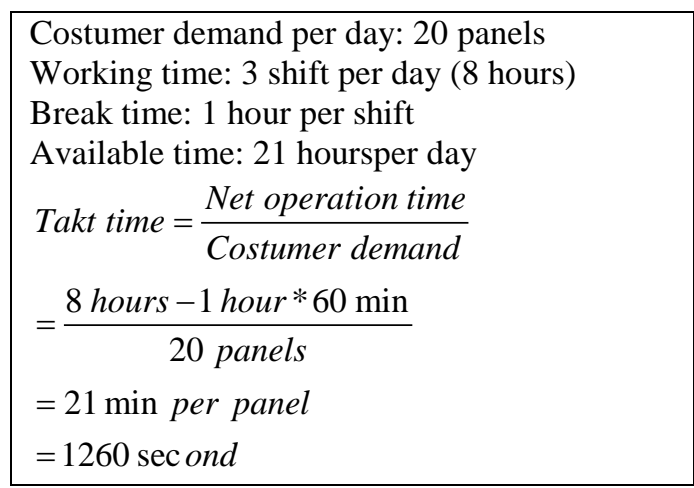

Fig. 2. Total cycle times current state of CVSS

From Fig. 2, we can see clearly the cycle time for each process exceeded the takt time which is 1260 seconds. So, that mean, a time to produce a time needed to produce one product to meet customer requirement. Therefore, for this process, takt time calculated as in Fig. 2.

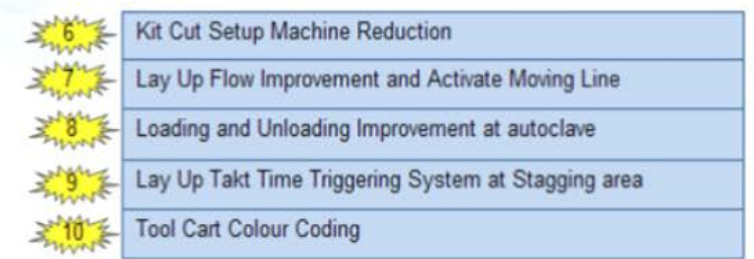

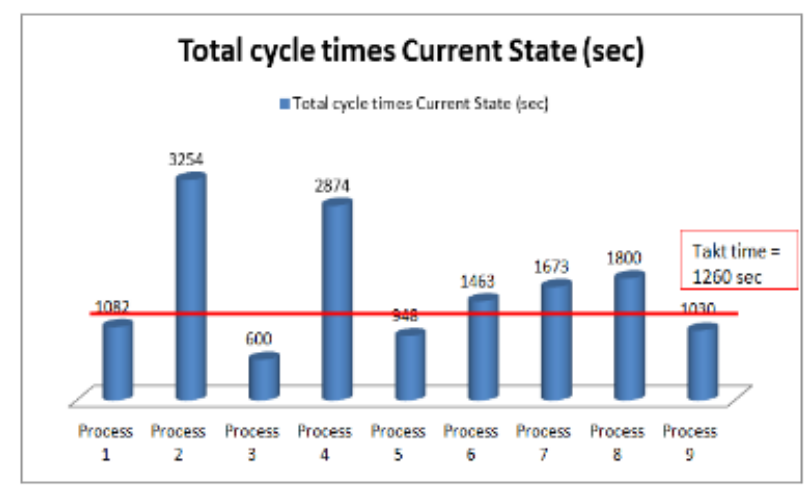

Total cycle times Current State (sec)

product is more than available time allocated. From Fig. 2, we know this is due to the bottleneck that occurs in those processes respectively. Therefore, 
VSM is a very good method to reduce all the cycle time to meet takt time to produce efficient and efficiency working time.

The purpose of current value stream mapping is to create a picture of how products flow through the value stream which is from raw materials to the customer's arm. For this research, Fig. 2 shows the current state map of the work processes as they currently exist in the company. It is important to understand the needs for changes and also where an opportunities lie. From the flow also, there are many items that can be identified and there will be room for improvement for solving problems.

Fig. 3 shows the total lead time of manufacturing process at studied company. Lead time is the total operating time to complete a cycle of product before moving to another product. Cycle time is total time require to complete task or process in making a product. From the result, we can estimate how much time needed to complete 1 unit of panel before it move to another process. Lead time also includes value added time and non-value added time. Table 1 shows summary of VA and NVA times.

Table 1. Summary of VA and NVA times

\begin{tabular}{|c|c|c|c|c|c|}
\hline \multicolumn{6}{|c|}{ Total Operation Time } \\
\hline $\begin{array}{l}\text { Ope- } \\
\text { rati- } \\
\text { on }\end{array}$ & Process & $\begin{array}{l}\text { VA } \\
\text { time }\end{array}$ & $\begin{array}{l}\text { NVA } \\
\text { time }\end{array}$ & $\begin{array}{l}\text { Cycle } \\
\text { time }\end{array}$ & $\begin{array}{c}\% \\
\text { Cycle } \\
\text { time } \\
\text { (to be } \\
\text { elimi- } \\
\text { nated) }\end{array}$ \\
\hline 1 & $\begin{array}{l}\text { Material } \\
\text { preparation }\end{array}$ & 1082 & 832 & 1914 & 43.47 \\
\hline 2 & $\begin{array}{l}\text { Lay up ply } \\
1-8\end{array}$ & 3254 & 759 & 4013 & 18.91 \\
\hline 3 & Compaction & 600 & 600 & 1200 & 50 \\
\hline 4 & $\begin{array}{l}\text { Lay up ply } \\
9-14\end{array}$ & 2874 & 457 & 3331 & 13.72 \\
\hline 5 & $\begin{array}{l}\text { Bagging } \\
\text { and leak } \\
\text { test process }\end{array}$ & 948 & 636 & 1584 & 40.15 \\
\hline 6 & $\begin{array}{l}\text { Wait and } \\
\text { move to } \\
\text { staging area }\end{array}$ & 1483 & 3271 & 4734 & 69.1 \\
\hline 7 & $\begin{array}{l}\text { Preparation } \\
\text { to cure \& } \\
\text { loading }\end{array}$ & 1673 & 1054 & 4627 & 58.76 \\
\hline 8 & $\begin{array}{l}\text { Autoclave } \\
\text { Cure }\end{array}$ & 10800 & 0 & 10800 & 0 \\
\hline 9 & $\begin{array}{l}\text { Unloading } \\
\text { and debag } \\
\text { process }\end{array}$ & 1030 & 2854 & 3886 & 73.49 \\
\hline & $\begin{array}{l}\text { TOTAL } \\
\text { LEAD } \\
\text { TIME }\end{array}$ & 23724 & 10465 & 34189 & \\
\hline
\end{tabular}

From Table 1, the total lead time for the whole operation is shown. Total lead times for this process are 34,189 seconds. Non value added contributes 10,465 seconds (30.61\%) that is used for nonproductive operation. The time used for creating value product which is value added time is 23,724 seconds (69.39\%). As company to manufacturer makes the profit, this kind of waste will increase the operation cost and also time for making product. The waiting time that occurred during manufacturing process is a major cause to the higher non value added times. This problem can be look at certain production area that contributes lots of waiting time and become bottleneck to the next operation process.

From the existing problems, the study will be conducted to minimize any possibility that can cause non value added operation and increase value added processes. CVSS will be used as a method to reduce the waste occurred.

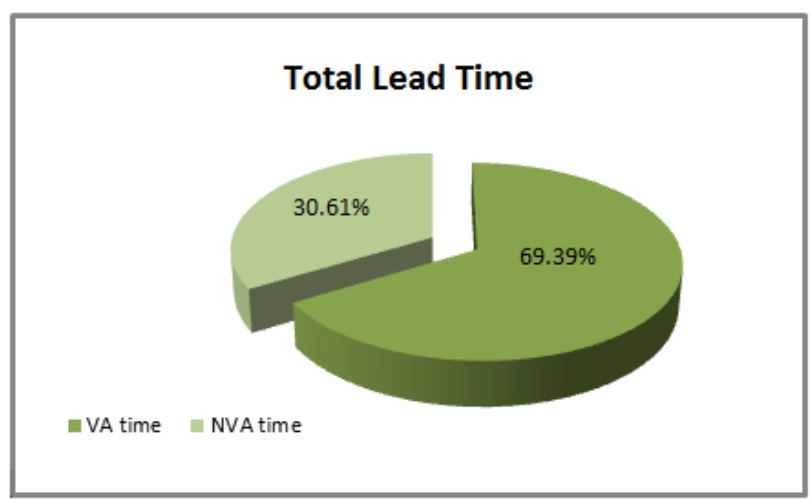

Fig. 3. Total lead time

From the chart, as a manufacturing company that makes profit, they need to eliminate or at least reduce their non-value added activity to make profits. This project deal with process improvement in the company using various Lean Manufacturing tools such as 5S and Value Stream Mapping. The main reason of using these tools is to identify waste in value streams in order to find an appropriate ways of elimination or at least to reduce it. Fig. 3 show total lead times of manufacturing process.

\section{Summary of Problems and Actions Taken}

From observation have been conducted, researcher found lots of problem occurs during company operation. Discussions of all waste identified and action taken for each Kaizen burst are as shown in Table 2 to Table 11. 
Table 2. New Rack for CLT (Circle Laminate Template) at Lay Up area

\begin{tabular}{|l|l|l|}
\hline \multicolumn{3}{|c|}{ New Rack for CLT (Circle Laminate Template) at Lay Up area } \\
\hline Complexity & $\begin{array}{l}\text { difficult to take because of the } \\
\text { ways it keep }\end{array}$ & Aesign new model of CLT rack \\
\hline Defect & $\begin{array}{l}\text { defect CLT surface because of the } \\
\text { friction between them }\end{array}$ & Make partition to eliminate friction \\
\hline Time & $\begin{array}{l}\text { use lots of times to find and take } \\
\text { before use }\end{array}$ & $\begin{array}{l}\text { Partition as easy way to take out CLT } \\
\text { from rack }\end{array}$ \\
\hline
\end{tabular}

Table 3. Relocate Bagging Material, Core Rack and CLT rack

\begin{tabular}{|l|l|l|}
\hline \multicolumn{3}{|c|}{ Relocate Bagging Material, Core Rack and CLT rack } \\
\hline Labor & $\begin{array}{l}\text { need more operator to push heavy } \\
\text { and big tool for cure at autoclave. }\end{array}$ & $\begin{array}{l}\text { Replace broken tool cart tyre with } \\
\text { new tyre. }\end{array}$ \\
\hline Space & $\begin{array}{l}\text { waste space because of the } \\
\text { unimportant type of material such } \\
\text { as prepreg box, sealant box etc. }\end{array}$ & Do 5S to manage space properly \\
\hline $\begin{array}{l}\text { Idle } \\
\text { Material }\end{array}$ & $\begin{array}{l}\text { Many pre preg carts pending at } \\
\text { lay-up space. Need more space to } \\
\text { keep pre-preg carts at lay-up area. }\end{array}$ & $\begin{array}{l}\text { Cut pre preg according to schedule. } \\
\text { Avoid idle material. }\end{array}$ \\
\hline
\end{tabular}

Table 4. Core, Kit Cut and Lay up Electronic Triggering System

\begin{tabular}{|l|l|l|}
\hline \multicolumn{4}{|c|}{ Core, Kit Cut and Lay up Electronic Triggering System } \\
\hline \multicolumn{3}{|c|}{ Waste identified } \\
\hline Complexity & $\begin{array}{l}\text { Have no specific report/format for } \\
\text { triggering Kit Cut and Core Supply to } \\
\text { lay Up }\end{array}$ & $\begin{array}{l}\text { Came out with specific format which } \\
\text { is can trigger Core and kit Cut }\end{array}$ \\
\hline $\begin{array}{l}\text { Visual } \\
\text { Control }\end{array}$ & $\begin{array}{l}\text { No single visibility to coordinate, } \\
\text { expedite and have the Kit Cut, Core } \\
\text { and Tooling to be synchronised }\end{array}$ & $\begin{array}{l}\text { To implement electronic control of } \\
\text { operations via single electronic } \\
\text { report or display }\end{array}$ \\
\hline Labor & $\begin{array}{l}\text { Have no specific PIC for each area to to } \\
\text { Log in the system }\end{array}$ & $\begin{array}{l}\text { Area manager to identify the name of } \\
\text { the PIC and forward it to Information } \\
\text { System department }\end{array}$ \\
\hline
\end{tabular}

Table 5. Lay up Plan Reshuffle

\begin{tabular}{|l|l|l|}
\hline \multicolumn{3}{|c|}{ Lay up Plan Reshuffle } \\
\hline Idle Material & $\begin{array}{l}\text { Mante identified } \\
\text { lay-up space. Need mending at } \\
\text { keep pre-preg carts at lay-up area. }\end{array}$ & $\begin{array}{l}\text { Kit Cut machine cut pre-preg } \\
\text { according to plan/ demand }\end{array}$ \\
\hline Overproduction & $\begin{array}{l}\text { Kit cut machine produce/cut pre- } \\
\text { preg more than requirement. A lot } \\
\text { of pre-preg cart pending at lay-up }\end{array}$ & $\begin{array}{l}\text { Reschedule Kit Cut operation to } \\
\text { follow demand. }\end{array}$ \\
\hline Transportation & $\begin{array}{l}\text { Heavy and big tool need to push } \\
\text { for long distance to autoclave }\end{array}$ & $\begin{array}{l}\text { Change big tool lay up line in middle } \\
\text { of lay-up up area, near to push carts } \\
\text { to autoclave area. }\end{array}$ \\
\hline Labor & $\begin{array}{l}\text { Need more operator to push } \\
\text { heavy and big tool for cure at } \\
\text { autoclave }\end{array}$ & $\begin{array}{l}\text { Replace broken tool cart tire with } \\
\text { new tire. }\end{array}$ \\
\hline
\end{tabular}

Table 6. Laser Tracking Utilization

\begin{tabular}{|l|l|l|}
\hline \multicolumn{3}{|c|}{ Laser Tracking Utilization } \\
\hline Complexity & $\begin{array}{l}\text { Too much access ply compare } \\
\text { actual size required. }\end{array}$ & Cut ply according to size required \\
\hline Overproduction & $\begin{array}{l}\text { Produces ply more than schedule } \\
\text { plan. Not enough Laser capacity. }\end{array}$ & $\begin{array}{l}\text { Kit cut produce ply according to } \\
\text { demand }\end{array}$ \\
\hline Transportation & $\begin{array}{l}\text { Heavy and big tool need to push } \\
\text { for long distance to Laser } \\
\text { Projector. }\end{array}$ & Move big tool line near to autoclave \\
\hline
\end{tabular}

Table 7. Kit Cut Machine Setup Reduction

\begin{tabular}{|l|l|l|}
\hline \multicolumn{3}{|c|}{ Kit Cut Machine Setup Reduction } \\
\hline Complexity & $\begin{array}{l}\text { Waste identified } \\
\text { direction. Dangerous for operator } \\
\text { to pick ply when machine } \\
\text { nunning. }\end{array}$ & Cut and write ply in one direction. \\
\hline Overproduction & $\begin{array}{l}\text { Kit cut machine produce/cut pre- } \\
\text { preg more than requirement. A lot } \\
\text { of pre-preg cart pending at lay-up }\end{array}$ & $\begin{array}{l}\text { Cut ply according to demand from } \\
\text { Material up }\end{array}$ \\
\hline Time & $\begin{array}{l}\text { Waste in material because } \\
\text { operator have tendency to pull } \\
\text { preg a lot more than required } \\
\text { cutting region (when not cutting } \\
\text { full table) }\end{array}$ & $\begin{array}{l}\text { Educate or train employees to avoid } \\
\text { pulling excess material. }\end{array}$ \\
\hline $\begin{array}{l}\text { Time consuming for setting up } \\
\text { programme. Operator scans by } \\
\text { batch and call out program one by } \\
\text { one. }\end{array}$ & $\begin{array}{l}\text { Reduce setup time by reschedule } \\
\text { scanning system }\end{array}$ \\
\hline
\end{tabular}

Table 8. Layup Improvement and Activate Moving Line

\begin{tabular}{|l|l|l|}
\hline \multicolumn{3}{|c|}{ Layup Flow Improvement and Activate Moving Line } \\
\hline Complexity identified & $\begin{array}{l}\text { complexity of movement and } \\
\text { process flow for HEXCELL } \\
\text { program }\end{array}$ & $\begin{array}{l}\text { Act lay-out HEXCELL program lay up } \\
\text { area }\end{array}$ \\
\hline Transportation & $\begin{array}{l}\text { Laminating Mold always queue } \\
\text { before entering lay up room }\end{array}$ & $\begin{array}{l}\text { Straight way for LM from entering } \\
\text { door to moving line }\end{array}$ \\
\hline Space & $\begin{array}{l}\text { waste space because not important } \\
\text { type of material such as prepreg } \\
\text { box, sealant box etc }\end{array}$ & Do 5S to manage space properly \\
\hline Time & $\begin{array}{l}\text { long time to take CLT due to long } \\
\text { distance }\end{array}$ & Reschedule time for entering time \\
\hline
\end{tabular}

Table 9. Loading and unloading improvement at Autoclave

\begin{tabular}{|l|l|l|}
\hline \multicolumn{3}{|c|}{ Loading and unloading improvement at Autoclave } \\
\hline Waste identified & \multicolumn{1}{c|}{ Action Taken } \\
\hline Complexity & $\begin{array}{l}\text { Difficult to load the autoclave rack } \\
\text { due to condition of rail }\end{array}$ & $\begin{array}{l}\text { Repaired and extend Autoclave rail } \\
\text { for A/C 1 \& A/C 2 }\end{array}$ \\
\hline Labor & $\begin{array}{l}\text { Constrains of manpower due to } \\
\text { same person doing loading, } \\
\text { unloading, put LM on the autoclave } \\
\text { \& debag process }\end{array}$ & $\begin{array}{l}\text { Manpower has been arranged equally } \\
\text { - request additional } \\
\text { manpower (8 person) to support 24/7 } \\
\text { schedule }\end{array}$ \\
\hline Time & $\begin{array}{l}\text { Found surface depression issue } \\
\text { suspected by vacuum coupler during } \\
\text { loading process }\end{array}$ & $\begin{array}{l}\text { Retrained all autoclave operator } \\
\text { based on Process resident work plan } \\
\text { (PRWP) }\end{array}$ \\
\hline $\begin{array}{l}\text { Take time for loading. Due to } \\
\text { damage or leaking vacuum hose, } \\
\text { problem of vacum port, leaking of } \\
\text { final bagging, undetected Tc wire }\end{array}$ & $\begin{array}{l}\text { checked and repaired vacuum } \\
\text { systems at all autoclave (piping } \\
\text { inside autoclave \& vacuum hose } \\
\text { itself) }\end{array}$ \\
\hline
\end{tabular}

Table 10. Layup takt time triggering systems at staging area

\begin{tabular}{|c|c|c|}
\hline \multicolumn{3}{|c|}{ Layup takt time triggering systems at staging area } \\
\hline & Waste identified & Action Taken \\
\hline Labor & $\begin{array}{l}\text { Operator walk \& take the material } \\
\text { by their own (stryder are not } \\
\text { effectiveness) }\end{array}$ & $\begin{array}{l}\text { Retrained to all stryder (the } \\
\text { functioning of water stryder) }\end{array}$ \\
\hline Transportation & $\begin{array}{l}\text { Have no enough tool cart \& it can } \\
\text { effect on daily output }\end{array}$ & $\begin{array}{l}\text { tool cart will run smoothly when the } \\
\text { bus schedule have been followed }\end{array}$ \\
\hline Time & Late supply of TC Wire & $\begin{array}{l}\text { autoclave bus schedule consistently } \\
\text { followed }\end{array}$ \\
\hline
\end{tabular}

Table 11. Tool cart color coding

\begin{tabular}{|l|l|l|}
\hline \multicolumn{3}{|c|}{ Tool cart color coding } \\
\hline Transportation & $\begin{array}{l}\text { Have not enough tool cart \& it } \\
\text { can effect on daily output }\end{array}$ & Maintained tool cart properly \\
\hline Time & $\begin{array}{l}\text { Operator cannot concentrate on } \\
\text { their job because need to walk to } \\
\text { find material }\end{array}$ & $\begin{array}{l}\text { Centralize material area. Easier for } \\
\text { operator to pick up. }\end{array}$ \\
\hline
\end{tabular}




\section{Future State of CVSS Analysis}

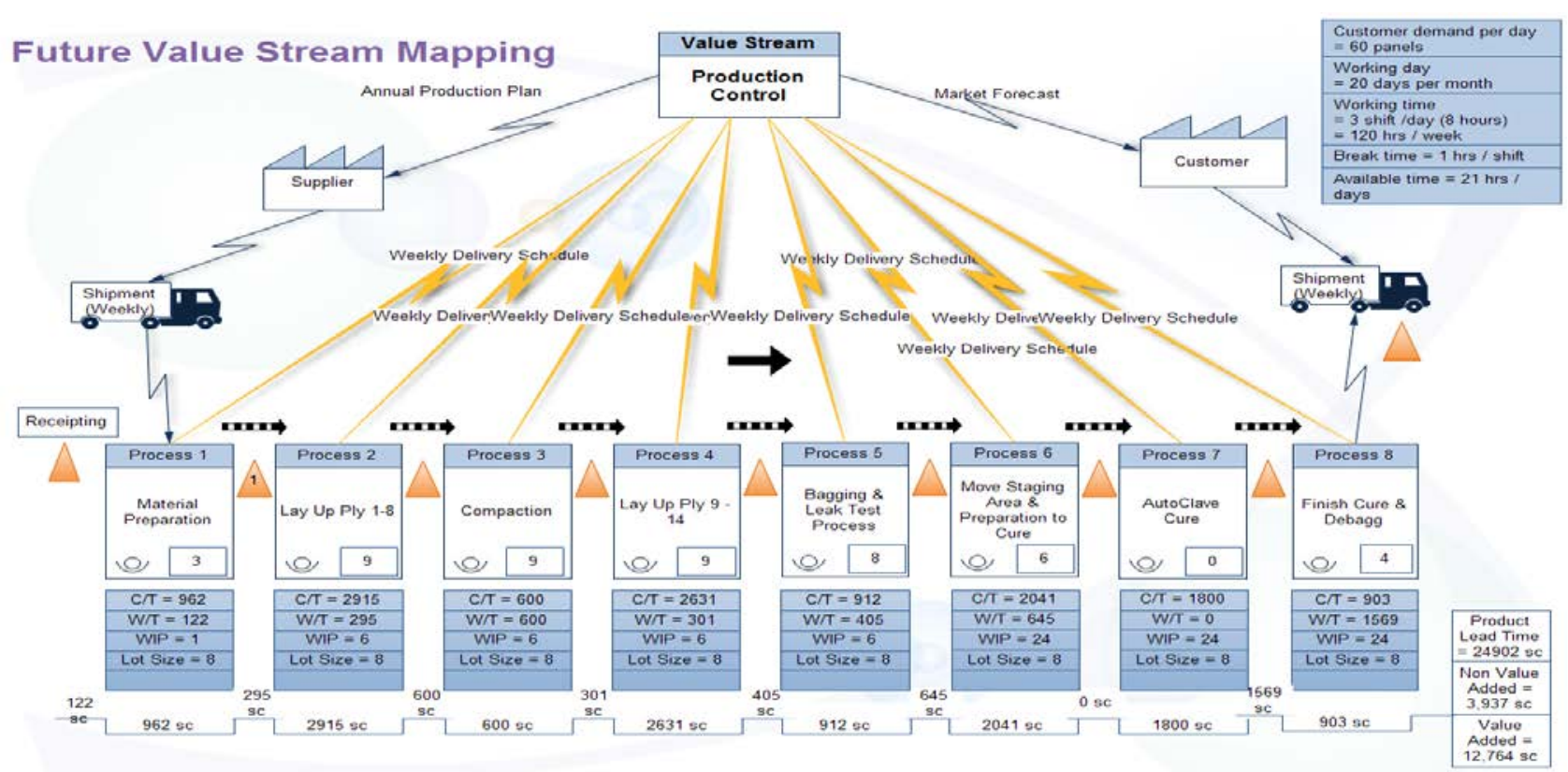

Fig. 4. Future State of CVSS

From the problems identified, kaizen burst have been done by Kaizen team for future state of value stream mapping in order to improve their operation. The comparison between current state of value stream mapping and future state of value stream mapping is shown in Table 12 below.

Table 12. Total time current and future CVSS

\begin{tabular}{|c|c|c|c|c|}
\hline \multirow{2}{*}{ Process } & \multicolumn{4}{|c|}{ Total cycle times } \\
\cline { 2 - 5 } & Current State (sec) & Future State (sec) & Total reduce & $\begin{array}{c}\% \\
\text { reduce }\end{array}$ \\
\hline $\begin{array}{c}\text { \# of } \\
\text { Operation }\end{array}$ & 9 processes & 8 processes & 1 & 12.5 \\
\hline Process 1 & 1914 & 1084 & 830 & 43.36 \\
\hline Process 2 & 4013 & 3210 & 803 & 20.01 \\
\hline Process 3 & 1200 & 1200 & 0 & 0.00 \\
\hline Process 4 & 3331 & 2932 & 399 & 11.98 \\
\hline Process 5 & 1584 & 1317 & 267 & 16.86 \\
\hline Process 6 & 4734 & 2686 & 4775 & 53.65 \\
\hline Process 7 & 2727 & 10800 & 0 & 0.00 \\
\hline Process 8 & 10800 & 2472 & 1414 & 36.39 \\
\hline Process 9 & 3886 & 25701 & 8488 & \\
\hline Total & 34189 & \multicolumn{3}{|c}{} \\
\hline
\end{tabular}

From Table 12, comparison between current state and future state of value stream mapping is shown. Before kaizen burst is implemented, the total operation is 9. But when kaizen burst have been applied to all the processes, 1 process operation have been reduce but still producing the same amount of product. This mean, the total cost and times for the operation have been reduced. This is what lean manufacturing aiming for.

From the analysis that have been done for current state of CVSS and the future state of CVSS, there are some reduction of time identified such as waiting times, total operation time and also total NVA time. Comparison of waiting time, total operation time and NVA time for current and future state is shown in Table 13.

Table 13. Total waiting time

\begin{tabular}{|c|c|c|c|c|}
\hline \multirow{2}{*}{ Process } & \multicolumn{4}{|c|}{ Total waiting times } \\
\cline { 2 - 5 } & $\begin{array}{c}\text { Current State } \\
(\mathrm{sec})\end{array}$ & $\begin{array}{c}\text { Future State } \\
(\mathrm{sec})\end{array}$ & total reduce & $\%$ reduce \\
\hline \# of Operation & 9 processes & 8 processes & 1 & 12.5 \\
\hline process 1 & 832 & 122 & 710 & 85.34 \\
\hline process 2 & 759 & 295 & 464 & 61.13 \\
\hline process 3 & 600 & 600 & 0 & 0.00 \\
\hline process 4 & 457 & 301 & 156 & 34.14 \\
\hline process 5 & 636 & 405 & 231 & 36.32 \\
\hline process 6 & 3271 & 645 & 3680 & 85.09 \\
\hline process 7 & 1054 & 0 & 0 & 0.00 \\
\hline process 8 & 0 & 1569 & 1287 & 45.06 \\
\hline process 9 & 2856 & 3937 & 6528 & 62.38 \\
\hline Total & 10465 & & &
\end{tabular}




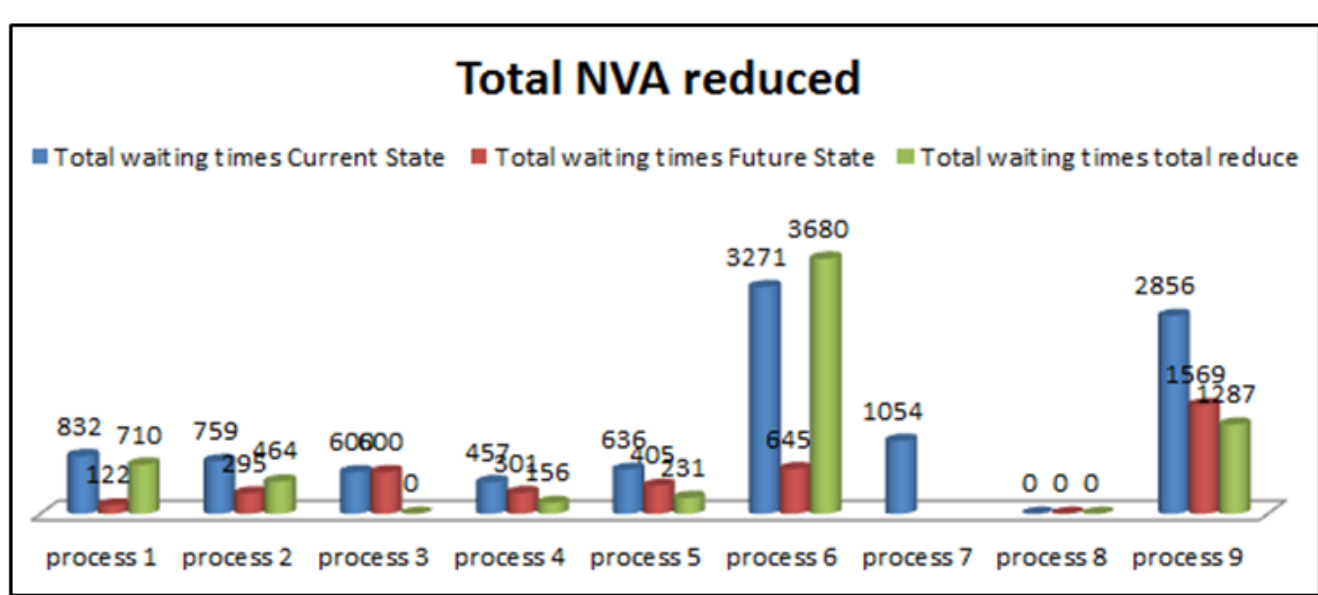

Fig. 5. Total NVA reduced

From Table 13 and Fig. 5, total waiting times for whole processes are 10,465 seconds for current state of value stream mapping and 3,937 seconds for future state of value stream mapping. From Fig. 5, the total waiting times reduction from process 1 till process 9 were 6,528 seconds or $62.38 \%$. It shows that CVSS can help lots of NVA times to reduce.

\section{Conclusion}

From the results of this paper, it is proven that CVSS can help manufacturing company to reduce their waste in production. Thus it will help the company to gain more profit after applying CVSS in their current production system. Most of all, the company made very good improvement towards lean manufacturing system by applying most of lean characteristic to increase their effectiveness and efficiency. In this paper, comparisons analysis was done between current state of value stream mapping and future state of value stream mapping using CVSS. The cycle times and waiting times analysis is done to reduce the total cycle times for the whole processes. This involved Kaizen system in order to suggest improvements.

\section{References}

[1] Womack J, Jones D, \& Ross D. The Machine that Changed the World. New York: Rawson Associates; 1990.

[2] Sohal. A. S. \& Egglestone A. Lean production: Experience among Australian organizations. International Journal of Operations \& Production Management 1994; 14(11): p. 35-51.

[3] Hancock, W. M. \& Zayko, M.J. Lean production implementation problems. IIE Solutions 1998; 30(6): p. 38-42.

[4] Womack, J. P. \& Jones, D. T. Lean Thinking. London: Simon \& Schuster; 1996.

[5] Nicholas J. Competitive Manufacturing
Management: Continuous Improvement, Lean Production, Customer-focused Quality. New York: Irwin/ McGraw-Hill; 1998.

[6] Rother, M. \& Shook, J. Learning to See Value Stream Mapping to Create Value and Eliminate Muda. The Lean Enterprise Institute, Brookline, MA. 1999.

[7] Seth, D. Seth, N. \& Goel, D. Application of value stream mapping (VSM) for minimization of wastes in the processing side of supply chain of cottonseed oil industry in Indian context. Journal of Manufacturing Technology Management 2008; 19(4): p. 529-550.

[8] Lasa, I. B. Laburu, C. O. \& Vila, R. C. An Evaluation of the Value Stream Mapping Tool. Business Process Management Journal 2008; 4(1): p. 39-52. 